\title{
Non-Keynesian Effects of Fiscal Consolidations in Central Europe in the Years 2000-2013
}

\author{
Adam P. Balcerzak and Elżbieta Rogalska
}

\begin{abstract}
Last two decades were a period of significant discussion concerning determinants of effectiveness of fiscal policy. After some cases of expansionary episodes of fiscal consolidations in eighties of XX century, an intensive international research on the possibility of non-Keynesian effects of fiscal contractions in highly developed countries has started. The aim of the article is to analyze the possibility of obtaining non-Keynesian effects of fiscal consolidations in posttransformation countries of Central Europe. An important aim of macroeconomic policy in the analyzed economies is to benefit the advantages of convergence process. Thus, the empirical analysis is made within conditional $\beta$-convergence framework. The verification of hypothesis of $\beta$-convergence enables to identify the long term tendency of output per capita, in the same time it enables to identify non-Keynesian effects of fiscal prudence and to assess their role in the process of reducing GDP gap between the analyzed economies. Then the potential transmission channels for non-Keynesian effects of fiscal policy were analyzed. In the research the data from Eurostat and European Commission for the years 2000-2013 was used. The paper provides arguments in favor of the existence of non-Keynesian effects of fiscal consolidations in Central Europe that support the process of conditional convergence.
\end{abstract}

Keywords Fiscal policy - Fiscal consolidations - Non-Keynesian effects • $\beta$-Conditional convergence $・$ Central Europe

\footnotetext{
A.P. Balcerzak $(\bowtie)$

Department of Economics, Nicolaus Copernicus University, Toruń, Poland

e-mail: apb@umk.pl

E. Rogalska

Department of Microeconomics, University of Warmia and Mazury, Olsztyn, Poland

e-mail: e.rogalska@interia.pl
} 


\section{Introduction}

Utilizing potential of convergence process is one of the most important economic long term problem of post-communist countries. In the same time, after global financial crises that started in the year 2008 almost all Central European economies face the problem of high government debt (see: Balcerzak 2009, 2013). As a result, these countries must prepare middle and long term strategies for fiscal deleverage process. Based on the traditional Keynesian approach, it is commonly believed that fiscal consolidations, which lead to significant macroeconomic deleverage, usually result in high short term cost in term of current product growth. However, some episodes of expansionary fiscal consolidations in Denmark and Ireland in eighties of XX century have started vigorous research on the possibility of obtaining non-Keynesian effects of fiscal negative adjustments. Thus, the question on the possibility and conditions of implementing fiscal consolidations, which do not result in negative influence on current product, should be considered as one of the most important macroeconomic policy problems for Central Europe. Successful application of fiscal austerity plans, which in the same time does not harm significantly short term GDP growth, would have important positive consequences for the convergence process in the region. As a result, the main aim of the article is to analyze the possibility of obtaining non-Keynesian effects of fiscal contractions in case of ten countries of Central Europe that joined European Union in 2004 and 2007. Thus, the following countries were analyzed: Bulgaria, Czech Republic, Estonia, Hungary, Latvia, Lithuania, Poland, Romania, Slovakia, and Slovenia.

In this context the most important novelty of the research presented in this work, which also distinguish the paper from previous articles on non-Keynesian effects in new European Union members states (Rzońca and Ciżkowicz 2005; Borys et al. 2014), is the analysis of the possibility of non-standard effects of fiscal consolidations within theoretical and empirical convergence framework.

The article consists of two parts. In the first one the theoretical background concerning non-Keynesian models and its potential common ground with the long term models of endogenous growth is discussed. In this part also the potential channels for transmission of fiscal shocks are pointed. The aim of this part is to find potential linkages between short term fiscal shocks resulted from consolidations and their potential influence on convergence process. The second part of the article is strictly empirical with econometric panel analysis. The analysis consists of two steps. First of all, the influence of fiscal austerity on current growth within conditional $\beta$-convergence framework is analyzed. Then the potential channels for transmission of the fiscal shocks and their role in creating non-Keynesian effects of fiscal policy is verified.

The empirical econometric analysis was done for the years 2000-2013. In spite of relatively short time series, the year 2000 was chosen deliberately as the starting point of the analysis. The nineties of XX century in case of Central and Eastern European countries made a period of fundamental institutional changes resulted from the process of transformation from communism to market economy. It is very 
difficult to point the exact year when these countries finished the transformation process. However, it is commonly stated that the transformation from communism to market economy was successfully finished in the end of nineties when the countries started negotiations with European Union on its enlargement. The data from Eurostat, European Commission Rapports and World Bank was used.

The research is a continuation of the analysis concentrating on the non-Keynesian cases of fiscal consolidations within conditional $\beta$-convergence framework for the first eleven Eurozone countries (Balcerzak et al. 2014a, b, c).

\section{The Theoretical Common Ground for Non-Keynesian Models of Fiscal Consolidations and Convergence Process}

The question concerning the influence of fiscal policy on the short and long term growth belongs to the core of contemporary macroeconomics from its very beginning. Based on the traditional dichotomy in macroeconomics it can be said that responsible (usually understood as restrictive) fiscal policy from the long term perspective tend to provide fundaments for long term growth, whereas in short term fiscal consolidations rather decrease aggregate demand and result in lower GDP growth (see more Balcerzak and Rogalska 2014). However, the experiences of Denmark and Ireland in the eighties of XX century have brought new insight on the possibilities of unconventional effects of fiscal contractions, where fiscal austerity under some circumstances even in the short term can result in increase of aggregate demand. As a result in the last decade of XX century intensive research on the possibilities of expansionary-non-Keynesian-effects of fiscal consolidations was started (Giavazzi and Pagano 1990, 1995).

The research that has been done for last two decades resulted in two complementary groups of models providing theoretical explanation for stimulating results of fiscal contractions. The demand side models concentrate on the expectations of private agents concerning the positive influence of fiscal consolidations on their future tax burden. The second group demand side models attribute the non-Keynesian effects of fiscal policy to the influence of possible lower fiscal burden, which is the result of fiscal consolidation, on cost level of enterprises and thus their competitiveness (Rzońca and Ciżkowicz 2005; Rogalska 2012).

In case of demand side models the transmission mechanism depends on the possible wealth effects of households. The households expecting that their future tax burden can be lower, in order to smooth their consumption during the lifespan, can increase current consumption, which under some positive circumstances can offset the negative impulse resulting from lower government expenditures. Both the theoretical and empirical literature provide three groups of factors that may be necessary for obtaining the positive wealth effects of fiscal contractions. These are scale of consolidations, credibility of authorities and budget situation before the 
consolidation episode. The scale of consolidations must be significant enough, which is crucial for convincing the households that the fiscal austerity will result in lower taxes in the future. In case of the credibility of government, the household must be sure that the government will not change discretionary its fiscal policy in case of some political factors. The difficult situation of the government budget can be a factor supporting the credibility of plans of fiscal consolidation. With unsustainable level of public debt the private agents expect the inevitable increase of fiscal burden. In that case significant and strict fiscal consolidations can convince the households to change their negative expectations (Alesina and Ardagna 1998, 2009; Perotti 1999).

On the other hand, the demand side models concentrate on the composition of fiscal adjustments. In that cases, the consolidations that are mostly the result of increase of government budged revenues through tax increases can lead to increasing wage pressure in enterprises, which depending on the situation on labor markets, can result in higher labour costs of enterprises. Thus, it can decrease their international price competitiveness. The negative influence of adjustment on enterprises can be the source of negative supply shock decreasing the chances for successful fiscal consolidation. However, in case of consolidations that are mainly the result of budged expenditure cuts obtained through lower expenditures on wages in public sector can additionally lead to lower wage pressure in private sector. This can increase the cost effectiveness of enterprises, support their investment capabilities and international competitiveness, which in some circumstances can be the source of positive supply shock leading to non-Keynesian effects of fiscal austerity (Alesina et al. 1999; Lane and Perotti 2001; Alesina and Ardagna 2009; Alesina and Perotti 1997).

To sum up, based on these two groups of models explaining non-Keynesian effects of fiscal consolidations one can point two transmission channels for not-standard fiscal impulses: (a) the domestic channel with the reaction of private investment and private consumption; (b) the external channel with reaction of export (see also Rzońca and Ciżkowicz 2005; Borys et al. 2014).

The models of non-Keynesian effects of fiscal contractions have some important common ground with the theoretical literature on convergence process. The possible positive influence of fiscal consolidations, which are based on effective change of structure of public expenditures, on the long term convergence process is deeply rooted in the models of endogenous growth (see more Barro and Sala-I-Martin 1991). In these models it is commonly assumed that the government revenues and expenditures can be classified to opposite categories: (a) distortionary taxation and non-distortionary taxation; (b) productive and non-productive expenditures. The distortionary taxation negatively influences middle and long term steady state rate of growth as they can discourage private agents from saving and investing both in physical and human capital. Thus, distortionary taxation decreases the speed of convergence process. On the other hand, the productive expenditures are usually defined as the once that can be included as arguments in the private production function. Thus, they can positively influence of steady state rate of growth (Kneller et al. 1999). As a result, the models of endogenous growth theory support the 
argumentation for the change of structure of government expenditure form non-productive to productive expenditures and avoiding the distortionary taxation, which can be obtained during fiscal consolidation actions. This is especially important in case of countries that face the problem of closing the development gap and using the potential of convergence process such as Central European economies. From that perspective one can talk about the common theoretical ground for concept of long-term conditional convergence and the short-term models of non-Keynesian fiscal consolidations (see also Balcerzak et al. 2014c).

\section{The Econometric Estimation of Conditional $\beta$-Convergence with Fiscal Policy and Transmission Channels of Fiscal Consolidations}

The aim of the econometric analysis is the evaluation of influence of fiscal adjustment on GDP and the verification of basic transmission channels of fiscal impulses. Based on the theoretical models of non-Keynesian effects discussed in previous section, the following potential transmission channels were pointed: the domestic channel with the reaction of private investment and private consumption; the external channel with reaction of export. The econometric procedure of estimation consists of two steps. In the first stage, the influence of fiscal adjustment on GDP with special concentration on non-Keynesian effects of fiscal consolidations and its potential influence on convergence process was tested. To fulfill this aim, conditional $\beta$-convergence framework was applied (Sala-I-Martin 1996; Pietrzak 2012) ${ }^{1}$ In the second stage the pointed potential channels for fiscal non-Keynesian impulses with panel models were evaluated.

The phenomena of $\beta$-convergence means that the analyzed countries in the long term converge in terms of income per capita within the long term steady state. In case of conditional $\beta$-convergence one assumes that every country tends to reach his own steady state, which is determined by economic processes that characterize the fundamental conditions of economy. Among these fundamental conditions one can find for example the investment rate, the depreciation, the population rate of growth, the quality of human capital, and the technology (Mankiw et al. 1992; Levine and Renelt 1992). In case of conditional $\beta$-convergence the countries can reach the same income level but only provided that they are similar in terms of economic variables that determine the output in the steady state (Balcerzak et al. 2014a, b).

The hypothesis of conditional $\beta$-convergence was tested by estimation of parameters of dynamic panel model that is described with the Eq. (3). As dependent

\footnotetext{
${ }^{1}$ Similar empirical approach was used for estimation of non-Keynesian effects of fiscal consolidations in case of first 11 members of Euro Zone in the years 1995-2013 (Balcerzak et al. 2014a, b, c).
} 
variable GDP per capita in purchasing power standards was used. As independent variable one could find primary balance defined as government net lending or net borrowing excluding interest. The primary balance makes the variable that characterizes the fiscal policy approach. The positive value of the variable is equivalent to government surplus whereas negative means the government deficit. In the context of the theoretical background described in Sect. 2 of the paper the parameter $\alpha_{1}$ should be positive and statistically significant.

$$
\begin{gathered}
G D P_{i t}^{*}=\beta_{0}-\beta_{1} \ln G D P_{i t-1}+\alpha_{1} D E F_{i t}+\boldsymbol{\eta}_{i}+\boldsymbol{\varepsilon}_{i t} \\
G D P_{i t}^{*}=\ln \left(G D P_{i t} / G D P_{i t-1}\right) \\
\ln G D P_{i t}=\beta_{0}+\gamma \ln G D P_{i t-1}+\alpha_{1} D E F_{i t}+\boldsymbol{\eta}_{i}+\boldsymbol{\varepsilon}_{i t} \\
\gamma=\left(1-\beta_{1}\right)
\end{gathered}
$$

where:

$G D P_{i t}$-the vector of GDP per capita, $G D P_{i t}^{*}$ - the vector of the rate of growth of GDP per capita, $D E F$ - the vector of primary balance describing fiscal prudence, $\beta_{0}, \beta_{1}, \alpha_{1}, \gamma$-the structural parameters of the model, $\boldsymbol{\eta}_{i}$-the vector of individual effects of a panel model, $\boldsymbol{\varepsilon}_{i t}$-the vector of disturbances.

All the variables are determined for i-country in the period t. Variables $D E F$ is the potential variable that determine the output in the steady state.

Obtaining statistically significant value of parameter $\gamma$ and its estimation at the level $\gamma<1$, which is equivalent to positive value of parameter $\beta_{1}$, verifies the hypothesis of conditional $\beta$-convergence for the analyzed countries. The convergence process occurs provided that all the countries are characterized with similar level of variables that determine the output in the steady state. In this case it is fiscal policy variable. The lower value of $\gamma$ (higher positive value of parameter $\beta_{1}$ ) the faster convergence process occur (Pietrzak 2012).

In the model of convergence described with the Eq. (1) the growth rate of GDP per capita depends on the fiscal policy prudence which is understood as restrictive fiscal policy approach. The positive estimate of the parameter $\alpha_{1}$ means that there is a positive influence of fiscal consolidations in a given period $t$ on the rate of growth of GDP per capita during all the period of analysis. It can be interpreted as the occurrence of non-Keynesian effects of fiscal policy for analyzed countries.

To estimate the parameters of model (3) the system GMM estimator was used (Blundell and Bond 1998), which is a development of first-difference GMM estimator (Holtz-Eakin et al. 1988; Arellano and Bond 1991). The idea of system GMM estimator is the estimation of both equations in first differences and equations in levels. The results of two-step estimation with asymptotic standard errors are presented in the Table 1. 
Table 1 The estimated conditional $\beta$-convergence model

\begin{tabular}{l|l|l}
\hline Parameter & Parameters estimation & $\mathrm{p}$-Value \\
\hline$\gamma$ & 0.997506 & $\approx 0.000$ \\
\hline$\alpha_{1}$ & 0.00946393 & $\approx 0.000$ \\
\hline Statistical tests & \multicolumn{2}{l}{} \\
\hline Sargan test & 9.24463 & 1 \\
\hline $\operatorname{AR}(1)$ & -2.6036 & 0.0092 \\
\hline $\operatorname{AR}(2)$ & -1.20526 & 0.2281 \\
\hline
\end{tabular}

The Sargan test enables testing of over-identifying restrictions (Blundell et al. 2000). The obtained statistic of the test was equal to 9.2, which means that the null hypothesis is rejected. All instruments were proper. Autocorrelation of the first-differenced of disturbances was tested too. The statistic of the test for firstorder serial correlation was equal to -2.6 , which means that the null hypothesis that there is no first-order serial correlation is rejected. The statistic of the test for second-order serial correlation was equal to -1.20526 , which means that the null hypothesis of no second-order serial correlation is not rejected (Baltagi 1995; Arellano and Bond 1991). It means that the system GMM estimator is consistent and efficient.

The parameter $\gamma$ is statistically significant. The estimate of the parameter $\gamma$ which is below 1 verifies the hypothesis of convergence. The parameter $\alpha_{1}$ is statistically significant. It means that variable $D E F$ significantly determine the convergence process for central European countries. The positive estimate of the parameter $\alpha_{1}$ suggests positive influence of restrictive fiscal policy on the convergence process and it can be interpreted as a confirmation of non-Keynesian effects of fiscal consolidations.

In the second stage of the econometric analysis the verification of the transmission channels of fiscal impulses was done. The estimation procedure was close to the approach applied by Rzońca and Ciżkowicz (2005) who were researching the possibilities of non-Keynesian effects of fiscal policy in case on new European Union members for the years 1993-2002. As a result three simple panel models were estimated: the Eq. (5) for the domestic channel with the reaction of private investment, the Eq. (6) the domestic channel with the reaction of private consumption, the Eq. (7) the external channel with reaction of export. In case of Eqs. (4) and (6) for controlling the most important determinants of private consumption and private investments beside the fiscal variable the GDP per capita and real interest rate were used. In case of Eq. (7) and determinants of export for the same purpose real effective exchange rate and the value of import in so called "old" European Union (UE-15) were used. The condition for positive verification of potential influence of every channel is obtaining positive and statistically significant value of estimation of parameter $\alpha_{2}$. All three models were estimated with pooled ordinary least squares (OLS) and fixed effects (FE) estimators. The models for all channels were estimated with the data from Eurostat and the data for real interest rate from World Bank. 
The domestic channel-reaction of consumption

$$
\Delta C O N_{i t}=\alpha_{0}+\alpha_{1} \Delta G D P_{i t}+\alpha_{2} D E F_{i t}+\alpha_{3} R I R_{i t}+{ }_{i}+\varepsilon_{i t}
$$

The domestic channel-reaction of investments

$$
\Delta I N V_{i t}=\alpha_{0}+\alpha_{1} \Delta G D P_{i t}+\alpha_{2} D E F_{i t}+\alpha_{3} R I R_{i t}+{ }_{i}+\varepsilon_{i t}
$$

The external channel with reaction of export

$$
\Delta E X P_{i t}=\alpha_{0}+\alpha_{1} \Delta G D P_{i t}+\alpha_{2} D E F_{i t}+\alpha_{3} \Delta I M P_{i t}+\alpha_{4} R E E R_{i t}+{ }_{i}+\varepsilon_{i t}
$$

where:

$\triangle C O N_{i t}$-vector of the first difference of private consumption per capita estimated with purchasing power standard in the i-country in the period $t$.

$\Delta G D P_{i t}$-vector of the first difference of GDP per capita estimated with purchasing power standard in the i-country in the period $\mathrm{t}$.

$D E F_{i t}$-vector annual change of primary balance in the i-country in the period t. $R I R_{i t}$-vector of real interest rate in the i-country in the period $\mathrm{t}$.

$\Delta I N V_{i t}$-vector of the first difference of investments per capita estimated with purchasing power standard in the i-country in the period $t$,

$\Delta E X P_{i t}$-vector of the first difference of export per capita estimated with purchasing power standard in the i-country in the period $t$,

$\Delta I M P_{i t}$-vector of the first difference of import in European Union countries

(EU-15) per capita estimated with purchasing power standard in the i-country in the period $\mathrm{t}$,

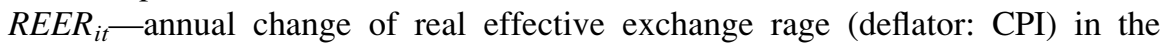
i-country in the period $\mathrm{t}$,

$\eta_{i}$ - the vector of individual effects of a panel model,

$\varepsilon_{i t}$ - the vector of disturbances.

Tables 2, 3 and 4 presents the results of estimations for Eqs. (5), (6) and (7) respectively. It can be seen that in case of both estimators the differences in results

Table 2 The estimated model for the domestic channel-reaction of consumption

\begin{tabular}{l|l|l|l|l}
\hline \multirow{2}{*}{ Parameter } & \multicolumn{2}{|l|}{ OLS } & FE estimator \\
\cline { 2 - 5 } & Parameters estimation & $\mathrm{p}$-Value & Parameters estimation & $\mathrm{p}$-Value \\
\hline$\alpha_{0}$ & 50.8022 & 0.1022 & 50.7724 & 32.0888 \\
\hline$\alpha_{1}$ & 0.601220 & $\approx 0000$ & 0.601275 & 0.0338885 \\
\hline$\alpha_{2}$ Statistical tests & -37.6493 & $\approx 0.000$ & -37.9617 & 0.0011 \\
\cline { 3 - 5 } & \multicolumn{2}{|l}{ Breusch-Pagan test } & $\begin{array}{l}\text { F-test for the null hypothesis that the } \\
\text { cross-sectional units all have a common } \\
\text { intercept }\end{array}$ \\
\cline { 2 - 5 } & Test statistics & p-Value & Test statistics & p-Value \\
\cline { 2 - 5 } & 3.94 & 0.05 & 0.15 & 0.99 \\
\hline
\end{tabular}


Table 3 The estimated model for the domestic channel-reaction of investments

\begin{tabular}{l|l|l|l|l}
\hline \multirow{2}{*}{ Parameter } & \multicolumn{2}{l}{ OLS } & FE estimator \\
\cline { 2 - 5 } & Parameters estimation & p-Value & Parameters estimation & p-Value \\
\hline$\alpha_{0}$ & -431.408 & $\approx 0.000$ & -439.956 & $\approx 0.000$ \\
\hline$\alpha_{1}$ & 0.803640 & $\approx 0.000$ & 0.816544 & $\approx 0.000$ \\
\hline$\alpha_{2}$ Statistical tests & 24.1210 & 0.0506 & 24.6501 & $\approx 0.000$ \\
\hline & \multicolumn{2}{|l|}{ Breusch-Pagan test } & $\begin{array}{l}\text { F-test for the null hypothesis that the } \\
\text { cross-sectional units all have a common } \\
\text { intercept }\end{array}$ \\
\cline { 2 - 5 } & Test statistics & p-Value & Test statistics & p-Value \\
\cline { 2 - 5 } & 0.02 & 0.9 & 1.05 & 0.41 \\
\hline
\end{tabular}

Table 4 The estimated model for the external channel with reaction of export

\begin{tabular}{|c|c|c|c|c|}
\hline \multirow[b]{2}{*}{ Parameter } & \multicolumn{2}{|l|}{ OLS } & \multicolumn{2}{|l|}{ FE estimator } \\
\hline & Parameters estimation & p-Value & Parameters estimation & p-Value \\
\hline$\alpha_{0}$ & 98.8554 & $\approx 0.000$ & 94.1441 & 0.2857 \\
\hline$\alpha_{1}$ & 0.817676 & $\approx 0.000$ & 0.824875 & $\approx 0.000$ \\
\hline$\alpha_{2}$ & 113.328 & $\approx 0.000$ & 111.047 & $\approx 0.000$ \\
\hline \multirow[t]{3}{*}{ Statistical tests } & \multicolumn{2}{|l|}{ Breusch-Pagan test } & \multicolumn{2}{|c|}{$\begin{array}{l}F \text {-test for the null hypothesis that the } \\
\text { cross-sectional units all have a common } \\
\text { intercept }\end{array}$} \\
\hline & Test statistics & p-Value & Test statistics & p-Value \\
\hline & 0.28 & 0.6 & 0.83 & 0.59 \\
\hline
\end{tabular}

of estimates of parameters are minor. In order to use the proper estimator BreuschPagan Test was used. It enables to verify the hypothesis on the existence of individual effects, which can point whether the pooled ordinary least square or estimator for individual effects should be used. In case of all the three models based on the results of Breusch-Pagan test it can be concluded that the implementation of individual effects is not necessary. Thus, simple pooled model with OLS estimator is adequate. This conclusion is confirmed with the results of F-test for the null hypothesis that the cross-sectional units all have a common intercept.

The results of estimation presented in Table 2 with statistically significant but negative estimate of the parameter $\alpha_{2}$ does not confirm the influence of domestic channel with the reaction of consumption in case of Central European countries in the year 2000-2010. It can be said that in the analyzed period the negative fiscal impulse was resulting in typical Keynesian reaction of private consumption. In case of domestic channel with the reaction of private investments the situation was different. The results of estimation in Table 3 with statistically significant (but in case of OLS estimator only with $10 \%$ level of significance) and positive estimate of the parameter $\alpha_{2}$ can be considered as confirmation of the influence of domestic channel with reaction of investment. Also in case of external channel with reaction of export in Table 4 one can find statistically significant and positive estimate of the parameter $\alpha_{2}$, which can be considered as an argument in favour of the influence of export channel. 


\section{Conclusions}

The conducted research on the influence of fiscal austerity on convergence process shows that in case of Central European countries in the years 2000-2013 restrictive fiscal policy was a significant factor of conditional $\beta$-convergence. From the policy point of view, it can be said that necessity for more restrictive middle term fiscal policy, under some circumstances, can become not an obstacle for current product growth, but it can be considered as a chance and possible factor supporting growth.

The obtained results in the sphere of potential transmission channels of non-Keynesian fiscal impulses are coherent with the analysis of Rzońca and Ciżkowicz (2005) for Central European countries for the years 1993-2002. They also identified unambiguously only one of the channels for non-Keynesian effects of fiscal adjustments, which was the external export channel. Contrary to the results in this paper they found some evidence confirming the existence of domestic consumption channel, but no evidence for influence of the domestic investment channel. On the other hand, the results obtained in this paper are very close to the estimation of Borys et al. (2014) for the same group of countries for the period 1995-2011. These researchers also found that investment and export were increasing after fiscal consolidation, whereas private consumption was not responding to the fiscal negative impulse in non-Keynesian way.

The empirical part of the article does not cover the problem of episodes of consolidations and strategies for their implementation. However, in case of future deleverage plans for Central European economies the verification of influence of both investment and export channels in the context of theoretical models, which were discussed in the first part of the article, can be considered as an argument for strategies of consolidations that focus on government expenditure cuts instead of increasing the budget revenues. This conclusion is also coherent with the results of analysis of strategies of consolidations with non-Keynesian effects in case of the first euro zone countries in the years 1995-2013 (Balcerzak et al. 2014a, b).

\section{References}

Alesina, A., \& Ardagna, S. (1998). Fiscal adjustments. Why they can be expansionary. Tales, of fiscal adjustment. Economic Policy, 13(27), 489-545.

Alesina, A., \& Ardagna, S. (2009). Large changes in fiscal policy: Taxes versus Spending. NBER Working Paper Series, 15438.

Alesina, A., Ardagna, S., Perotti, R., \& Schiantarelli, F. (1999). Fiscal policy, profits and investment. NBER Working Papers, 7207.

Alesina, A., \& Perotti, T. (1997). The welfare state and competitiveness. American Economic Review, 87(5), 921-939.

Arellano, M., \& Bond, S. (1991). Some tests of specification for panel data: Monte Carlo evidence and an application to employment equation. Review of Economic Studies, 58(2), 277-297.

Balcerzak, A. P. (2009). Przegląd i wstępna ocena teoretycznych stanowisk dotyczących źródeł globalnego kryzysu gospodarczego [Survey and Initial Assessment of Theoretical Stances on 
the Sources of Global Economic Crises]. In S. Antkiewicz \& M. Pronobis (Eds.), Gospodarka w warunkach kryzysu (pp. 257-274). Warszawa: Wydawnictwo Naukowe CeDeWu.pl.

Balcerzak, A. P. (2013). Poziom obciążeń fiskalnych w Polsce po globalnym kryzysie finansowym na tle pozostałych krajów Unii Europejskiej [The Level of Fiscal Burden in Poland After the Global Financial Crisis in Comparison to Other Countries of the European Union]. In W. Olkowska (Ed.), Ekonomika i finanse w procesie rozwoju gospodarki rynkowej. Aspekty globalne I lokalne (pp. 241-256). Olsztyn: Wydawnictwo Wyższej Szkoły informatyki i Ekonomii TWP.

Balcerzak, A. P., Pietrzak, M. B., \& Rogalska E. (2014a). Fiscal Contractions in Eurozone in the Years 1995-2013. Can Non-Keynesian Effects Be Helpful in Future Deleverage Process? In: Proceedings of the 14th Eurasia Business and Economics Society Conference Series: Eurasian Studies in Business and Economics, Vol. 2, Springer.

Balcerzak, A. P., Pietrzak, M. B., \& Rogalska E. (2014b). Fiscal contractions in Eurozone in the years 1995-2013. Can non-Keynesian effects be helpful in future deleverage process? Institute of Economic Research Working Papers, 13/2014.

Balcerzak, A. P., Pietrzak, M. B., \& Rogalska, E. (2014c). Niekeynesowskie skutki polityki fiskalnej $\mathrm{w}$ krajach strefy euro, ze szczególnym uwzględnieniem wpływu na proces konwergencji gospodarczej [Non-Keynesian Effects of Fiscal Policy in Euro Zone Countries with Special Consideration of Influence on Economic Convergence]. Przeglad Statystyczny, 61 (4), 389-407.

Balcerzak, A. P., \& Rogalska, E. (2014). Crowding out and crowding in within Keynesian framework. Do we need any new empirical research concerning them? Economics and Sociology, 7(2), 80-93.

Baltagi, B. H. (1995). Econometric analysis of panel data. Chichester: Wiley.

Barro, R. J., \& Sala-I-Martin, X. (1991). Convergence across states and regions. Brookings Papers on Economic Activity [online]. Accessed March 10, 2015, from http://www.brookings.edu/ / media/Projects/BPEA/1991-1/1991a_bpea_barro_salaimartin_blanchard_hall.PDF

Blundell, R., \& Bond, S. (1998). Initial conditions and moment restrictions in dynamic panel data model. Econometric Review, 87(1), 115-143.

Blundell, R., Bond, S., \& Windmeijer, F. (2000). Estimation in dynamic panel data models: Improving on the performance of the standard GMM estimator. In B. Baltagi (Ed.), Nonstationary panels, panel cointegration and dynamic panels (pp. 53-91). Amsterdam: Elsevier Science.

Borys, P., Ciżkowicz, P., \& Rzońca, A. (2014). Panel data evidence on the effects of fiscal policy shocks in the EU new member states. Fiscal Studies, 35(2), 189-224.

Giavazzi, F., \& Pagano, M. (1990). Can severe fiscal contractions be expansionary? Tales of two small European countries. In O. Blanchard \& S. Fisher (Eds.), Macroeconomics Annual 1990 (pp. 82-92). MA: MIT Press.

Giavazzi, F., \& Pagano, M. (1995). Non-Keynesian effects of fiscal policy changes: International evidence and the Swedish experience. NBER Working Paper Series, 5332.

Holtz-Eakin, D., Newwey, W., \& Rosen, H. (1988). Estimating vector autoregressions with panel Data. Econometrica, 56, 1371-1395.

Kneller, R., Bleaney, M. F., \& Gemmell, N. (1999). Fiscal policy and growth: Evidence from OECD countries. Journal of Public Economics, 74(2), 171-190.

Lane, P. R., \& Perotti, R. (2001). The importance of composition of fiscal policy: Evidence from different exchange rate regimes. Trinity College Dublin, Department of Economics, Trinity Economics Papers, 200116.

Levine, R., \& Renelt, D. (1992). A sensitivity analysis of cross-country growth regressions. American Economic Review, 82(4), 942-963.

Mankiw, N. G., Romer, D., \& Weil, D. N. (1992). A contribution to the empirics of economic growth. Quarterly Journal of Economics, 107(2), 407-427.

Perotti, R. (1999). Fiscal policy in good times and bad. Quarterly Journal of Economics, 114(4), 1399-1436. 
Pietrzak, M. B. (2012). Wykorzystanie przestrzennego modelu regresji przełącznikowej w analizie regionalnej konwergencji w Polsce [The use of a spatial switching regression model in the analysis of regional convergence in Poland]. Ekonomia i Prawo, XI(4), 167-185.

Rogalska, E. (2012). Efektywność stymulacyjnej polityki fiskalnej państwa w warunkach kryzysu zaufania budżetowego [Effectiveness of expansionary fiscal policy under conditions of state fiscal crisis]. Oeconomia Copernicana, 4, 5-22.

Rzońca, A., \& Ciżkowicz, P. (2005). Non-Keynesian effects of fiscal contraction in new member states. European Central Bank, Working Papers Series, 519/September.

Sala-I-Martin, X. (1996). The classical approach to convergence analysis. Economic Journal, 106 (437), 1019-1036. 